University of Nebraska - Lincoln

DigitalCommons@University of Nebraska - Lincoln

October 1998

Female Empowerment: The Influence of Women Representing Women

Angela High-Pippert

University of St. Thomas, ahighpippe@stthomas.edu

John Comer

University of Nebraska-Lincoln, jcomer1@unl.edu

Follow this and additional works at: https://digitalcommons.unl.edu/poliscifacpub

Part of the Political Science Commons

High-Pippert, Angela and Comer, John, "Female Empowerment: The Influence of Women Representing Women" (1998). Faculty Publications: Political Science. 2.

https://digitalcommons.unl.edu/poliscifacpub/2

This Article is brought to you for free and open access by the Political Science, Department of at DigitalCommons@University of Nebraska - Lincoln. It has been accepted for inclusion in Faculty Publications: Political Science by an authorized administrator of DigitalCommons@University of Nebraska - Lincoln. 


\title{
Female Empowerment: The Influence of Women Representing Women
}

\author{
Angela High-Pippert \\ John Comer
}

\begin{abstract}
The concept of political empowerment has been applied to ethnic and racial minorities, where it has been shown to positively influence political attitudes and participation. We examine whether political empowerment has the same positive consequences for women. Using data from the 1992 National Election Study and Almanac for American Politics 1990, 1992, and 1994, we explore whether women who are represented by women in Congress are more likely to be interested in and participate in politics, have a greater sense of political efficacy, competence, and trust, and evaluate Congress as an institution more favorably than women represented by men. In general, we find women who are represented by women are more interested, participate more, and have greater senses of political efficacy and political competence. Moreover, the findings clearly seem to be a function of empowerment rather than other factors that might account for both the election of a woman to Congress and differences in attitudes and behavior identified above. [Article copies available for a fee from The Haworth Document Delivery Service: 1-800-342-9678.E-mail address: getinfo@haworthpressinc.com]
\end{abstract}

It is has become fashionable to speak of empowerment, and it is not hard to find references in the news and elsewhere to individuals, groups, and communities that are described as empowered. Political empowerment, a special case, is often used when discussing those

The authors wish to thank Donley Studlar, Sue Thomas, and Susan Welch for their helpful suggestions on earlier versions of this manuscript.

Women \& Politics, Vol. 19(4) 1998

(C) 1998 by The Haworth Press, Inc. All rights reserved. 53 
who are disadvantaged in terms of political power, such as minorities (Bobo and Gilliam 1990; Gilliam 1996). While there is no agreed upon definition of the term, we find the definition presented by Bobo and Gilliam (1990) useful for our purposes. For them, political empowerment is "the extent to which a group has achieved significant representation and influence in political decision making."

One might expect political empowerment to be reflected in public policies beneficial to the empowered group. Evidence suggests black empowerment reflected in the election of black public officials has resulted in public policies beneficial to African Americans (Browning, Marshall, and Tabb 1984; Dye and Renick 1981; Eisinger 1982, 1983; Hall-Saltzstein 1989; Meier and England 1984; Mladenka 1989; Stein 1986;). Similarly, Hispanic empowerment results in policies beneficial to Hispanics (Mladenka 1989). Women, too, benefit from the election of women (Saltzstein 1986).

One might also expect political empowerment to influence political attitudes. Gilliam (1996) suggests two models for how black empowerment might affect the political orientations of blacks. A "symbolic politics" model assumes blacks represented by blacks will be more positive toward government. The "presence of highly visible black elected officials raises group pride as group members receive broad psychic benefit derived from the governing activities of black politicians" (Gilliam 1996, p. 69). A "governing coalitions" model assumes only blacks who are part of the governing coalition will be more positive toward government. In general, he finds support for the "governing coalitions" but not the "symbolic politics" model in a study of black, white, and Mexican American expressions of support for Mayor Tom Bradley in Los Angeles.

The election of black officials may provide symbolic satisfaction for blacks, but it may not be sufficient to generate a sense of empowerment that impacts on political attitudes. Support for the " governing coalitions" model suggests that the attitudinal consequences of black empowerment are contingent upon the delivery of some kind of concrete benefits.

While they do not distinguish a symbolic from a governing coalltion model, Bobo and Gilliam (1990) compare the attitudes and behaviors of African Americans in cities with black mayors to those 
with white mayors and find that in cities with black mayors, blacks are more politically active. They are more likely to participate in politics. They are also more knowledgeable about government and more trusting of local public officials. Political empowerment, as defined above, appears, at least among blacks, to influence some important political attitudes and behaviors.

Our research asks whether political empowerment has attitudinal consequences for other groups, namely women. We examine whether being represented by a woman in Congress as opposed to a man has empowering consequences similar to those for African Americans in cities with black mayors. In particular, the research explores whether women represented by a woman in the House of Representatives are more likely to be interested in, discuss, and participate in politics, have a greater sense of political efficacy, political competence, and political trust, and are more positive toward the institution of Congress. It would be difficult to delineate a governing coalitions model with our data; however, ours can minimally be viewed as a test of symbolic empowerment. We expect that women do take pride in and derive psychic benefit from the public service of other women and this produces more favorable attitudes toward the political system and contributes to higher levels of political participation. Symbolic political empowerment should not, however, lead to a vote for the incumbent or a higher job approval rating of the institution. Both are likely to be influenced by membership in the "governing coalition," that is, being among those who identify with the incumbent and/or the majority controlling Congress, but not among women in general. Thus, we expect no differences between women who are represented by a woman and women who are represented by a man in support for the incumbent or job approval of Congress.

While the experience of women is clearly different from the experience of blacks, there is reason to believe that women and blacks might be impacted in the same way by political empowerment. Both have experienced discrimination and obstacles to political participation which limit their political representation and power. Both are beginning to enjoy political success in terms of electing their own to political office. Moreover, political empowerment appears to have consequences for both minorities and women in terms 
of delivering public policies that benefit them. While these conditions do not guarantee that political empowerment will impact on the attitudes of women as it does African Americans, they provide a basis for hypothesizing that they do.

\section{CONTROL VARIABLES}

Research relevant to the inquiry concerns factors that impact on the political attitudes of women and factors that impact on the election of women to public office. While a great deal of research confirms differences between men and women in political attitudes (Cook 1979; Shapiro and Mahajan 1986), there are also differences among women. Explanations for these differences focus on political socialization and gender consciousness, as well as demographic and situational factors (Bennett and Bennett 1992).

Some women eschew political activity because they have been taught that politics is something that is best left to men. Others do not view politics and political activity as something for which they are ill suited because they are women. Differences in political socialization are most likely to occur between younger and older women and those with and without a college education (Bennett and Bennett 1992).

Women also vary in the degree to which they respond to gender concerns. Some identify themselves with feminism and/or the feminist movement. While others avoid these labels and may not know exactly what they mean, they still are sensitive to issues affecting women, feel a sense of pride in the accomplishments of women, and are angry about the way women are treated. Such women are likely to feel differently on a range of issues from women who are less gender conscious (Conover 1988). Such women tend to be better educated and affluent (Erikson and Tedin 1995). Gender consciousness may be particularly important in explaining differences on women's and moral issues (Clark and Clark 1996).

Demographic and situational variations among women also produce differences in attitudes. Education alters one's political as well as social outlook in a number of ways. It is one of the strongest predictors of women's political involvement and participation (Bennett and Bennett 1992). Income and occupation also lead to 
variation in political attitudes among women. Personal situations also play a role. Some women are wives and mothers, while others remain single. Some work in the home, while others pursue careers. Some do both. Research has shown that the gender gap is most pronounced among single, well educated women (Weisberg 1987). Working women are more likely to believe that women should share equally in running business, industry and government than homemakers do (Erikson and Tedin 1995). They are also more likely to participate in politics (Anderson 1975). Professional women are even more likely to feel this way (Erikson and Tedin 1995; Klein 1984). In practice, it is difficult to sort out the specific influence of each of the above, but all need to be controlled in any analysis that seeks to account for differences in attitudes among women.

Another concern is establishing the proper causal connection among the variables. Our hypothesis is that the election of a woman is an empowering event that leads to certain attitudes among women. It is conceivable, however, that it is these and related attitudes that lead to the election of a woman. It may be that the election of a woman does not lead, for example, to higher levels of political trust among women but that women are elected from districts where women have higher levels of political trust. Contextual factors such as median income and education, community size, and minority population are correlated with women running for and getting elected to local public office (Darcy, Welch, and Clark 1994). The number of professional women in a state and the number of organizations representing women's interests impact on the number of women elected to state legislatures (Rule 1990; see also Rule 1981; Studlar and Matland 1994). Controlling for context should reduce the prospect that attitudes, particularly the ones we are examining, lead to the election of a woman rather than the reverse.

The analysis below tests the following hypothesis: Controlling for the effects of socialization, gender consciousness, demographic variations, situation, and context, the election of a female representative to Congress is an empowering event for women with positive consequences for political involvement and participation, efficacy, 
competence, and trust, and attitudes toward Congress as an institution.

\section{METHOD}

Data are taken from the 1992 National Election Study (NES) ${ }^{1}$ and Almanac of American Politics 1990, 1992, and 1994. The 1992 NES study identified the congressional district where a respondent resided in 1990. If the district was the same in 1992 as in 1990 and the incumbent sought re-election in 1992, the gender of the representative elected from the district-information taken from the $\mathrm{Al}$ manac of American Politics-was added to the data for each respondent in the 1992 study. Thus, in addition to variables on interest in political campaigns, political participation, and several attitudinal measures in 1992, we have the gender of the representative who was elected from the respondent's district in 1990 and re-elected in 1992. From this, we can distinguish between women represented by a woman, women represented by a man, men represented by a woman, and men represented by a man.

Interviews were conducted in 1992 in ten districts in ten states represented by a woman in 1990 and twenty-nine districts in twenty-nine states represented by a man in 1990 . Focusing only on districts that did not change between 1990 and 1992, that is, where the incumbent was running for reelection in the same district he/she represented in 1990, leaves the following breakdown of respondents and representatives. There are 77 female respondents who were represented by a woman, 742 female respondents represented by a man, 86 male respondents represented by a woman, and 650 male respondents represented by a man. While the primary concern is in comparing women represented by a woman with women represented by a man, male respondents represented by a man or woman provide another basis for comparison and another control.

\section{ANALYSIS}

Table 1 contains the adjusted mean values ${ }^{2}$ for each of the four groups on several attitudinal and behaviorial measures. The means 
TABLE 1. Selected Dependent Measures by Female Empowerment

\begin{tabular}{|c|c|c|c|c|c|}
\hline & $\begin{array}{l}\text { Women } \\
\text { Represented } \\
\text { by Woman }\end{array}$ & $\begin{array}{l}\text { Women } \\
\text { Represented } \\
\text { by Man }\end{array}$ & $\begin{array}{l}\text { Men } \\
\text { Represented } \\
\text { by Woman }\end{array}$ & $\begin{array}{l}\text { Men } \\
\text { Represented } \\
\text { by Man }\end{array}$ & $\begin{array}{l}\text { Statistical } \\
\text { Significance }\end{array}$ \\
\hline $\begin{array}{l}\text { 1. Number of Days Past } \\
\text { Week Discussed } \\
\text { Politics with Family } \\
\text { and Friends }\end{array}$ & 2.63 & 2.50 & 2.51 & 2.59 & $.06 ; .22$ \\
\hline $\begin{array}{l}\text { 2. Frequency of Political } \\
\text { Discussion with Family } \\
\text { and Friends }\end{array}$ & 2.30 & 2.19 & 2.22 & 2.22 & $.00 ; .94$ \\
\hline $\begin{array}{l}\text { 3. Number of Campaign } \\
\text { Programs Watched on TV }\end{array}$ & 2.10 & 2.12 & 2.14 & 2.15 & $.07 ; .30$ \\
\hline $\begin{array}{l}\text { 4. Political } \\
\text { Participation }\end{array}$ & 4.36 & 4.31 & 4.34 & 4.33 & $.01 ; .57$ \\
\hline $\begin{array}{l}\text { 5. Thermometer rating of } \\
\text { Congress }\end{array}$ & 52.32 & 51.59 & 49.49 & 51.17 & $.38 ; .03$ \\
\hline $\begin{array}{l}\text { 6. Thermometer rating of } \\
\text { Federal Government }\end{array}$ & 48.59 & 47.81 & 47.97 & 46.03 & $.29 ; .00$ \\
\hline 7. Political Efficacy & 8.41 & 7.82 & 8.01 & 8.33 & $.00 ; .03$ \\
\hline 8. Political Competence & 12.68 & 12.35 & 12.49 & 12.49 & $.09 ; .98$ \\
\hline 9. Political Trust & 7.97 & 7.90 & 7.94 & 7.77 & $.35 ; .01$ \\
\hline $\begin{array}{l}\text { 10. Cares about Outcome of } \\
\text { Election for House }\end{array}$ & 2.88 & 2.80 & 2.78 & 2.80 & $.03 ; .70$ \\
\hline $\begin{array}{l}\text { 11. Voted in House } \\
\text { Election }\end{array}$ & 1.89 & 1.87 & 1.88 & 1.87 & $.01 ; .01$ \\
\hline $\begin{array}{l}\text { 12. Voted for House } \\
\text { Incumbent }\end{array}$ & .80 & .80 & .80 & .79 & $.49 ; .54$ \\
\hline $\begin{array}{l}\text { 13. Job Approval of } \\
\text { Congress }\end{array}$ & 3.11 & 3.11 & 3.05 & 3.14 & $.43 ; .00$ \\
\hline
\end{tabular}

Note: The first set of coefficients in the last column reflect the comparison of women represented by a woman with women represented by a man. The second set of coeficicients reflect the comparison of men represented by a woman with men represented by a man.

are the predicted scores on each measure for each group derived from regressing the particular measure on the following: age, education, marital status, party identification, folded party identification, region (South/non-South), a measure reflecting whether women should have more, equal, or less power than men in govern- 
ment, business, and industry, ${ }^{3}$ whether the person identifies as a feminist, ${ }^{4}$ a scale reflecting gender consciousness, ${ }^{5}$ ADA score of the member representing the district, and percent of the district with a college education. ${ }^{6}$ Age and education control for socialization as well as important demographic differences among women; the power of women in government and business, self identification as a feminist, and the scale of gender consciousness control for gender consciousness; and marital status controls for situation. Region, ADA score, and percent college educated control for context. ADA serves as a surrogate for ideology in the district, and education for the socio-economic character of the district.

The first two columns of Table 1 address the empowerment hypothesis, and of the thirteen comparisons, all but one are in the expected direction. For women represented by a woman, interest in politics, reflected in the number of days and the frequency with which one discussed politics with family and friends, is higher than for women represented by a man. Relationships are statistically significant at .06 and .00 respectively (see first set of figures in column 5). Moreover, lack of statistical significance (see second set of figures in column 5) and adjusted means lower (2.51 compared to 2.59) and equal (2.22 compared to 2.22) for men represented by a woman compared to men represented by a man suggest that these differences reflect empowerment rather than district/cultural differences that might explain the election of a woman as well as higher interest in politics among women. In terms of motivating women to discuss politics, symbolic political empowerment appears to make a difference. Empowerment does not, however, make a difference with respect to monitoring political campaigns on television. Here, there is no difference between women represented by a woman and women represented by a man. While this represents a pattern contrary to the hypothesis, it is the only instance where this occurs.

All of the remaining relationships are in the expected direction, and most, particularly those tied to political involvement, are statistically significant. For example, empowerment is related to political participation, ${ }^{7}$ political efficacy, ${ }^{8}$ and political competence. ${ }^{9}$ Women represented by a woman are more likely to engage in a number of political activities, feel that they can influence the political process, and feel that they are sufficiently competent to do so than women 
represented by a man. Again, lack of a relationship for men represented by a woman compared to men represented by a man in political participation and competence suggests that something like empowerment rather than district/cultural differences are at work here. In the case of political efficacy, it is men who are represented by a women who are less efficacious than men represented by a man, adding weight to our conclusion that it is not some district/cultural phenomena that accounts for both the election of a woman and higher levels of participation and involvement on the part of women. The thermometer ratings of Congress and the federal government reveal that women represented by a woman are also more positive in their evaluations than women represented by a man. However, these differences are not statistically significant. As one might expect, the empowerment thesis seems to have more significance for political action and attitudes related to the responsiveness of government in general and one's competence than evaluations of specific institutions. Until women gain a significant presence in national institutions, it may be unreasonable to believe that empowerment will make much of a difference in how they feel about these institutions.

While the hypothesized pattern occurs with respect to political trust, ${ }^{10}$ the difference is not statistically significant. Moreover, political trust is one variable where men represented by a woman are higher than men represented by a man, giving pause to our initial dismissal that district/cultural factors are not at work in explaining our findings. Perhaps both empowerment and a district/cultural factor are at work. The weight of the evidence suggests, however, that empowerment is the more significant factor, and confirms that symbolic empowerment can make a difference in some important, and fairly stable, dispositions toward the political system.

Symbolic empowerment also impacts on concern with the outcome of the election for the House and voting in House elections. Women represented by a woman express greater concern and are more likely to vote, although the difference is small.

Voting for the incumbent and job approval of Congress are two areas where symbolic empowerment is expected to make little difference, and this is what we find. There is no difference between women represented by a woman or a man on these measures. One can argue that what we have found is not the positive residue of 
support for a particular incumbent, but something that does derive from the pride and psychic benefit that accrues from the public service of women. That there is no difference in job approval rating also suggests that it is specifically symbolic empowerment that is important here and not the need to produce something tangible and concrete in order to generate positive impacts. To the degree that the attitudes of blacks are not influenced by symbolic empowerment, our findings suggest that women may be satisfied with less in terms of representation than blacks, at least at this stage of their mobilization, and that their level of deprivation, less severe than blacks to be sure, may not require as much in the way of representation to produce a discernable impact on political attitudes and behavior.

\section{CONCLUSION}

Historically, minorities, in particular blacks, and women have suffered from a lack of political representation and influence. Both are beginning to see their numbers grow among elected public officials. Political empowerment of this kind is not only likely to lead to public policies beneficial to the group but also to changes in political attitudes and behavior on the part of group members. The analysis tests whether the election of women to Congress is an empowering event for women, impacting in a positive way on political participation and political attitudes. The evidence, while uneven, on balance suggests that women represented by a woman are empowered with positive consequences for political involvement and participation, as well as political efficacy and political competence. Being represented by a woman does not, however, lead to greater support for the incumbent or higher job approval ratings of Congress. The findings imply that it is the act of being represented by a woman itself, rather than any particular benefits that women derive from a female representative, that produces the difference. It appears women do derive psychic benefit from the election and governing activities of other women. Should specific benefits be a part of this, we might expect the relationships to be stronger and more consistent. Moreover, the fact that men who are represented by a woman compared to men who are represented by a man do not show higher levels of participation and supporting 
attitudes suggests that empowerment is the key here and not some district specific or cultural difference that explains the election of a woman as well as these higher levels.

While our findings are intriguing, they are not necessarily the last word on the matter. Additional study is warranted. First of all, the number of women who are represented by a woman is not particularly large. As more women get elected to Congress as well as other offices, we can test the thesis anew. One avenue of further inquiry with respect to women in Congress might be to add more districts to the analysis by comparing women in the 1994 NES election study who resided in a district that elected a woman in 1992 and as well as those who reelected a woman in 1992 with women who resided in a district that elected a man in 1992 and reelected a man in 1992. This would provide four groups to compare. One might also attempt to sort out-although cell sizes will be a problem-women who identify with the ideological position of their representative and those who do not, in an effort to assess the relative impact of the symbolic versus a governing-coalition model, or the difference between the psychic benefit derived from being represented by a woman and the concrete benefits derived from being represented by a woman.

There is also the possibility that our findings are an artifact of history, as 1992 was heralded as the "Year of the Woman." This may have impacted women in a positive way, but in a way that is unlikely to continue at the same rate. Here also, the answer is additional research.

Manuscript received for review: January 24, 1996 Final manuscript received: July 1, 1997

\section{NOTES}

1. Response rate to the NES was 65 percent.

2. Adjusted mean values are the mean value of OLS predicted scores for a dependent variable regressed on one or more independent variables. In this case, the mean values for women represented by a woman, women represented by a man, men represented by a woman, and men represented by a man are the mean values of the relevant dependent variable for each group with the effects of the independent variables controlled. The means are adjusted in the sense that any variation in the dependent variable accounted for by the independent variables is removed, increasing the prospect that any observed differences between the groups are a result of the groups themselves. 
3. The question asks, "Thinking about how you would like things to be in government, business, and industry, do you think men should have more power and influence, that men and women should have about equal power and influence, or that women should have more power and influence?"

4. The question asks, "Do you think of yourself as a feminist or not?"

5. The following questions are included. "How often do you find yourself feeling a sense of pride in the accomplishments of women?" (Very often, some of the time, occasionally, or almost never) "How often do you find yourself angry about the way women are treated in society?" (Very often, some of the time, occasionally, or almost never) "When reading or listening to the news, how much attention to you pay to issues that especially affect women?" (A lot, some, a little, or not at all) A measure of internal consistency, alpha, for the three items is .66.

6. Education is used here as opposed to income and other indicators of socioeconomic status because it is less subject to cost of living variations from one region of the country to another, which can make comparisons among congressional districts problematic. Moreover, it seems to us that education is the contextual variable most likely to impact on the attitudes we are examining and reflect district tendencies in terms of electing a woman to public office.

7. Political participation is measured as a simple additive scale combining the following: whether the respondent demonstrated support with a button, bumper sticker, or sign; attended a meeting, rally, or dinner; worked in a campaign; and contributed financially. Alpha for the four items is .61 .

8. Political efficacy is measured by agreement or disagreement with the following statements: "People like me have no say about what the government does," "Public officials do not care what people like me think," "Government and politics is too complicated for people like me to understand." Alpha for these items is .65.

9. Political competence comprises whether the respondent agrees or disagrees with the following statements: whether he/she understands the important problems facing the United States; is well qualified to participate in politics; could do as good a job in public office as others; and is better informed about politics and government than most. Alpha is 78 .

10. Political trust reflects responses to the following: "How much of the time can you trust the government in Washington to do what is right-just about always, most of the time, only some of the time," "Do you think the people in government waste a lot of the money paid in taxes, waste some of it, or don't waste much," "Do you think quite a few of the people running the government are crooked, not very many are, or hardly any are crooked," How much do you feel that elections make the government pay attention to what the people think-a good deal, some, or not too much." Alpha is .63.

\section{REFERENCES}

Andersen, Kristi. 1975. "Working Women and Political Participation." American Jounal of Political Science 19: 439-454.

Bennett, Stephen Earl, and Linda M. Bennett. 1992. "From Traditional to Modern Conceptions of Gender Equality in Politics: Gradual Change and Lingering Doubts." Western Political Quarterly 45: 93-111. 
Bobo, Lawrence, and Franklin Gilliam. 1984. "Race, Sociopolitical Participation and Black Empowerment." American Political Science Review 84: 377-393.

Browning, Rufus P., Dale Rogers Marshall, and David H. Tabb. 1990. Protest is Not Enough: The Struggle of Blacks and Hispanics for Equality in Urban Politics. Los Angeles, CA: University of California Press.

Clark, Cal, and Janet Clark. 1996. "Whither the Gender Gap? Converging and Conflicting Attitudes among Women." In Women in Politics, ed. Lois Lovelace Duke. Upper Saddle River, NJ: Prentice Hall.

Cook, Fay L. 1979. Who Should Be Helped? Beverly Hills, CA: Sage Publications.

Conover, Pamela Johnston. 1988. "Feminists and the Gender Gap." Journal of Politics 50: 985-1010.

Darcy, R., Susan Welch, and Janet Clark. 1994. Women, Elections, and Representation. Lincoln, NE: University of Nebraska Press.

Dye, Thomas R., and James Renick. 1981. "Political Power and City Jobs: Determinants of Minority Employment." Social Science Quarterly 62: 475-486.

Gilliam, Frank D., Jr. 1996. "Exploring Minority Empowerment: Symbolic Politics, Governing Coalitions and Traces of Political Style in Los Angeles." American Journal of Political Science 40: 56-81.

Eisinger, Peter K. 1982. "Black Employment in Municipal Jobs: The Impact of Black Political Power." American Political Science Review 76: 330-92.

Eisinger, Peter K. 1983. "The Politics of Racial Economic Advancement," Culture, Ethnicity, and Identity: Current Issues in Research, ed. William C. McCreadey. New York: Academic Press.

Erikson, Robert S., and Kent L. Tedin. 1995. American Public Opinion. Needham Heights, MA: Allyn and Bacon.

Hall-Saltzstein, Grace. 1989. "Black Mayors and Police Policies." Journal of Politics 51: 525-544.

Klein, Ethel. 1984. Gender Politics. Cambridge, MA: Harvard University Press.

Meier, Kenneth J., and Robert E. England. 1984. "Black Representation and Education Policy: Are They Related?" American Political Science Review 78: 38-49.

Mladenka, Kenneth D. 1989. "Blacks and Hispanics in Urban Politics." American Political Science Review 83: 165-192.

Rule, Wilma. 1981. "Why Women Don't Run: The Critical Contextual Factors in Women's Legislative Recruitment." Western Political Quarterly 34: 60-77.

Rule, Wilma. 1990. "Why More Women Are State Legislators." Western Political Quarterly 43: 437-448.

Saltzstein, Grace H. 1986. "Female Mayors and Women in Municipal Jobs." American Journal of Political Science 30: 140-164.

Shapiro, Robert Y., and Harprett Mahajan. 1986. "Gender Differences in Policy Preferences, A Summary of Trends from the 1960s to the 1980s." Public Opinion Quarterly 50: 42-61. 
Stein, Lana. 1986. "Representative Local Government: Minorities in the Municipal Workforce.” Journal of Politics 48: 694-713.

Studlar, Donley, and Richard E. Matland. 1994. "The Growth of Women's Representation in the Canadian House of Commons and the Election of 1984: A Reappraisal,” Canadian Journal of Political Science 27: 53-80.

Weisberg, Herbert. 1987. "The Demographics of a New Voting Gap: Marital Differences in American Voting.” Public Opinion Quarterly 51: 335345. 